GEOLOGICAL SURVEY CIRCULAR 296

\title{
STRATIGRAPHY OF THE \\ WASATCH RANGE NEAR \\ SALT LAKE CITY, UTAH
}

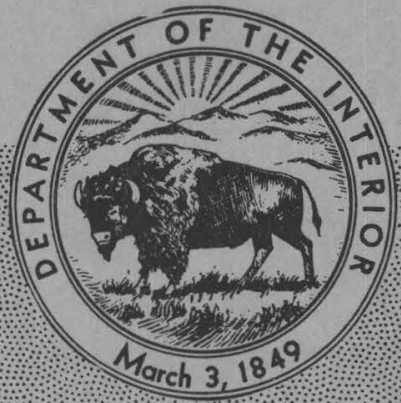



UNITED STATES DEPARTMENT OF THE INTERIOR

Douglas McKay, Secretary

GEOLOGICAL SURVEY

W. E. Wrather, Director

GEOLOGICAL SURVEY CIRCULAR 296

STRATIGRAPHY OF THE WASATCH RANGE NEAR SALT LAKE CITY, UTAH

By Arthur E. Granger 


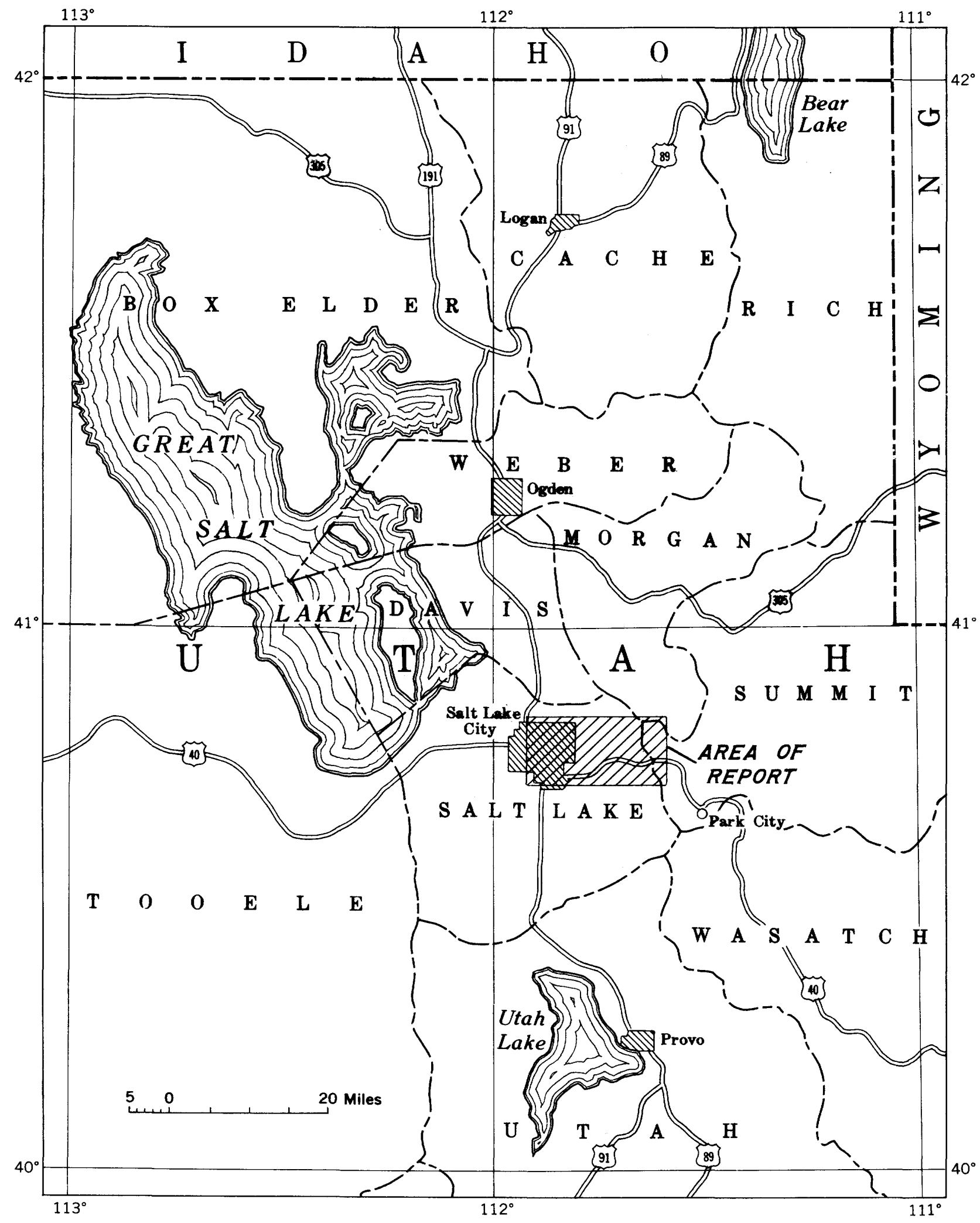

Index map of north-central Utah showing area of report. 


\title{
STRATIGRAPHY OF THE WASATCH RANGE NEAR SALT LAKE CITY, UTAH
}

\author{
By Arthur E. Granger
}

\section{CONTENTS}

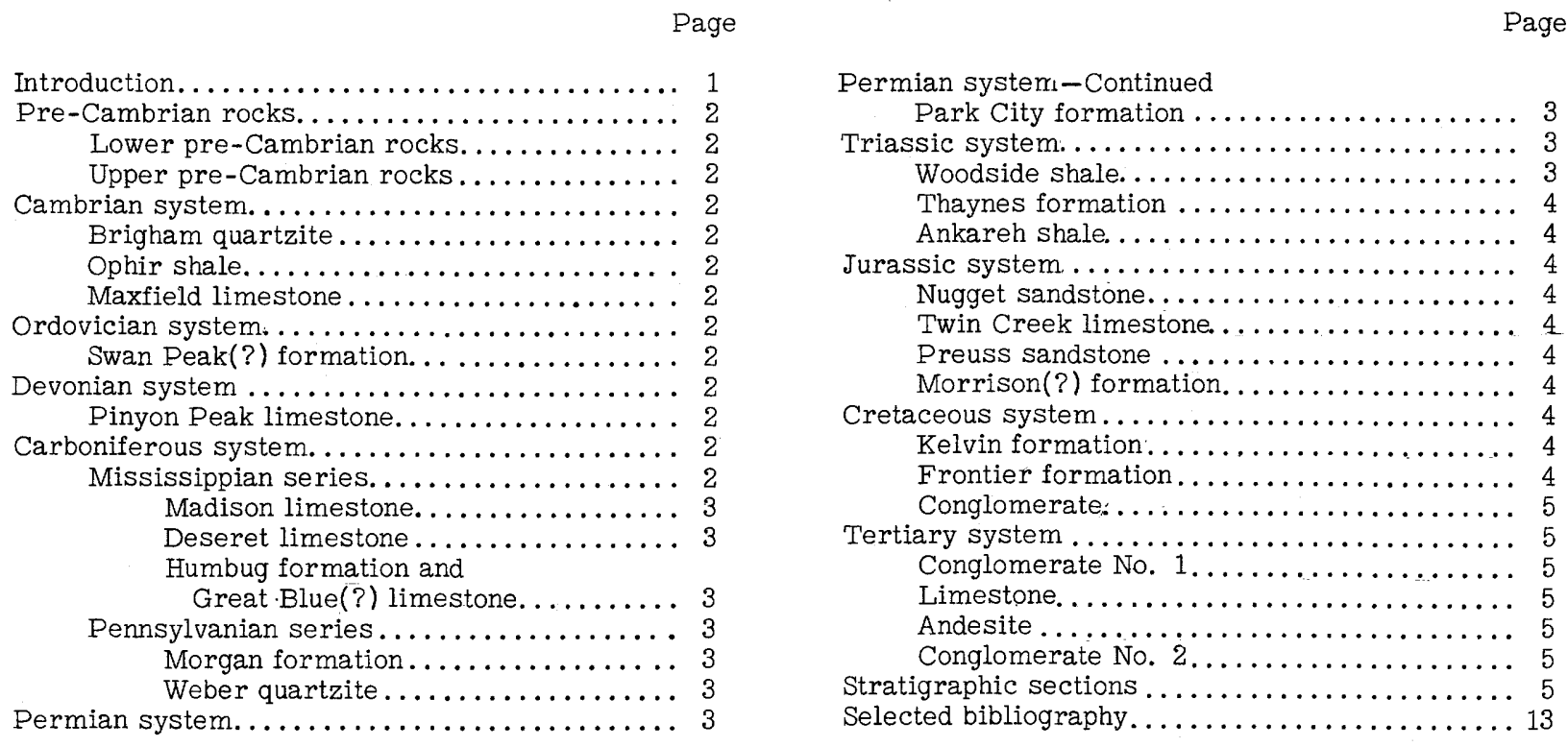

\section{ILLUSTRATIONS}

[Plates in pocket]

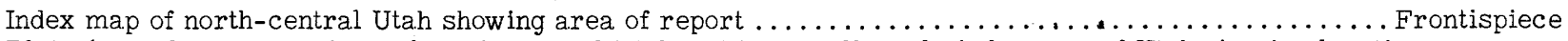
Plate 1. Columnar sections of north-central Utah, with a small-scale index map of Utah showing location of sections.

2. Geologic map and sections showing distribution and structure of rock units of the Wasatch Range near Salt Lake City, Utah.

\section{INTRODUCTION}

The area covered in this report (see frontispiece) extends from City Creek Canyon on the north to Parleys Canyon on the south and from the crest of the Wasatch Range on the east to the Wasatch mountain front and the Great Salt Lake valley on the west.

Much stratigraphic work has been done in the region, beginning with the U. S. Geological Survey of the 40th Parallel and followed by more local and detailed work by Blackwelder (1910), Boutwell (1912), Mathews (1931), Calkins (1943), Butler (1943), Eardley (1944), and others. However, in this particular area the first detailed mapping was begun by the U. S. Geological Survey in 1947 with A. E. Granger in charge. B. J. Sharp assisted in the field and office work in 1948 and 1949. Partial results of this survey are incorporated in the Utah Geological Society Guidebook of the Geology of the central Wasatch Mountains, Utah. Columnar sections that illustrate the results of studies in north-central Utah, and.an index map showing their location, are given in plate 1.

The work is part of a program of geologic mapping in the Wasatch Range and neighboring areas. Nearby areas in which work is under way are the Provo area by A. A. Baker, the Tintic area by T. S. Lovering and others, and the Cottonwood area by Frank C. Calkins and M. D. Crittenden, Jr. A report on the StocktonFairfield area (Gilluly, 1932) has been published.

The sedimentary rocks exposed in the Wasatch Range east of Salt Lake City range from pre-Cambrian 
rocks to rocks of early Tertiary age or younger. The general distribution and structure of the units distinquished in the area are shown in plate 2, and their character is indicated in the detailed stratigraphic sections on pages 5-14. Color terms by which the units are described are those given in the rock color chart of the National Research Council (Goddard and others, 1948). The following discussion supplements information contained in the descriptions of the measured sections.

\section{PRE-CAMBRIAN ROCKS}

\section{Lower pre-Cambrian rocks}

Lower pre-Cambrian rocks crop out to the north of the mapped area and in some places form its boundary. No actual mapping of these complex rocks was attempted. The series of crystalline schists, gneisses, and metaquartzites have been described by Eardley (1944, p. 823) and Bell (1952, p. 38-50).

\section{Upper pre-Cambrian rocks}

South of the area, particularly in the Cottonwood district, several thousand feet of phyllites, tillites, argillites, and quartzites crop out beneath the Cambrian rocks (Calkins, 1943). In the City Creek area these rocks are missing, except for small areas of quartzite and quartzite conglomerate in City Creek Canyon, but in the area under consideration they are about 700 feet thick and are pale olive to pale orange pink, with a green pebbly bed, possibly of tillite, at the top. It has been suggested that this part of the area was a highland without deposition during Proterozoic time (Eardley, 1944, p. 827).

\section{CAMBRIAN SYSTEM}

As shown in the accompanying detailed sections. Cambrian rocks of the City Creek area are composed of Brigham quartzite (Tintic quartzite of the Cottonwood district), Ophir shale, and the Maxfield limestone.

Brigham quartzite. -The Brigham quartzite is a uniform medium-to coarse-grained white quartzite, which weathers pale pink and has a maximum thickness of 995 feet where measured just north of Rotary Park in City Creek Canyon. Near the bottom are quartzite conglomerates.

In the Cottonwood district to the south, a persistent angular unconformity is exposed at the base of the Tintic quartzite which is equivalent to the Brigham quartzite in City Creek Canyon, but this angular unconformity has not been observed in the City Creek Canyon area, where the Brigham quartzite is overlain conformably by 400 feet of Ophir shale.

Ophir shale. - The Ophir shale is the lowest formation that can be identified with certainty, by the fossils it contains, as being of Cambrian age. It is a three-unit formation about 400 feet thick. Its lower 250 feet is composed of dull olive-green micaceous shale that contains poor but identifiable Cambrian. trilobite fragments, and irregular traillike markings. The middle member consists of 80 feet of blue-gray to whitish limestone, consistently marked by wavy or crinkly brown laminae which make the rock identifiable even in small fragments. The upper member consists of limy shale that weathers yellowish brown and is characterized by a blocky fracture.

Maxfield limestone. - The Maxfield limestone is a varied unit which conformably overlies the Ophir shale. It crops out in City Creek Canyon where it is 1, 039 feet thick. It also crops out at Becks Hot Springs on the west front of the Salt Lake salient. The Maxfield limestone consists mainly of thick - to thin-bedded, mediumto light-gray mottled limestone. Some dolomitic beds are present near the top of the formation.

\section{ORDOVICIAN SYSTEM}

Swan Peak(?) formation. - Tan to brown quartzitic rocks that overlie the Maxfield limestone are tentatively correlated with the Swan Peak formation of Ordovician age in the Randolph area (Richardson, 1941 , p. 16). The Swan Peak(?) formation is composed of coarse-grained pale yellowish-brown to white quartzite and has a measured thickness of 294 feet in City Creek Canyon and about the same thickness on the west face of the Salt Lake salient. The Swan 'Peak(?) formation is apparently conformable with the underlying Maxfield limestone. The contact at the base of the quartzite is not well exposed, but there appears to be no angular discordance between it and the underlying beds.

\section{DEVONIAN SYSTEM}

Pinyon Peak limestone. - A limestone unit referred to as Pinyon Peak limestone has yielded fossils of Late Devonian age. It crops out in the Rotary Park area of City Creek Canyon and also on the Salt Lake City salient east of the Salt Lake Refining Company plant. It is composed of fossiliferous bluish-gray and mottled limestone and has a characteristic flaggy fracture. It has a thickness of 159 feet where measured near Rotary Park. The contact with the underlying Swan Peak(?) formation is exposed over a very limited area but no conclusive evidence of angular unconformity was observed.

Edvaldson (1947, Utah Univ. unpublished thesis, p. 39) considered this limestone to be somewhat younger than the Jefferson dolomite. Field studies by Jean M: Berdan, Helen Duncan, and Mackenzie Gordon, Jr., of the U. S. Geological Survey (1951 and 1952), and faunal studies by A. J. Boucot, J. M. Berdan, and H. Duncan (1953) have shown that this unit is similar lithologically and faunally to the typical Pinyon Peak limestone of the Tintic district. The Pinyon Peak limestone of north-central Utah contains certain fossils characteristically found in the Ouray limestone, Percha shale, and the upper part of the Three Forks shale and appears to be the approximate temporal equivalent of these formations.

\section{CARBONIFEROUS SYSTEM}

\section{Mississippian series}

The Mississippian series includes the Madison limestone, the Deseret limestone, and the Humbug formation. 
Madison limestone. - The Madison limestone overlies the Pinyon Peak limestone with apparent concordance. It consists of thick- to thin-bedded mediumdark bluish-gray fossiliferous limestone and dolomite which is cherty toward the top. This formation contains fossils of early Mississippian age. It was measured in City Creek Canyon where it is about 650 feet thick.

\section{Deseret limestone.-The Deseret limestone} overlies the Madison limestone with apparent concordance. It is about 450 feet thick as measured in City Creek Canyon and consists mostly of cherty mediumgray to light-gray dolomitic limestone. The contact between the Deseret limestone and the underlying Madison limestone has been drawn at the base of a persistent black shale about 40 feet thick which commonly contains a little phosphate. This dark-colored basal shale is overlain in City Creek Canyon by more than 400 feet of dolomite and limestone that are darker in color (but weather slightly lighter), more cherty, and poorer in fossils than the underlying Madison limestone. This unit is correlated with the Deseret limestone of the Oquirrh Mountains (Gilluly, 1932, p. 25). The Deseret limestone generally contains fossils of late Mississippian (Brazer) age.

Humbug formation and Great Blue(?) limestone. The Humbug formation of late Mississippian age overlies the Deseret limestone conformably. The lower part of the formation consists of 727 feet of sandstone, dolomite, and limestone. The dolomites and limestones are somewhat fossiliferous and are dark and medium gray in color. The sandstones are pale yellowish brown for the most part.

A distinctive upper limestone, 372 feet thick, which may be correlative with the Great Blue limestone, has been mapped together with the Humbug formation. This distinctive unit is of local extent and consists of dark-gray to black limestone which weathers very light gray. It is fine grained, medium bedded, and fossiliferous throughout and is regarded as late Mississippian in age. According to Baker (Baker, Huddle, and Kinney, 1949, p. 1177):

\begin{abstract}
***a definite correlation of the relatively thin limestone and shale of the sections in upper American Fork and Cottonwood Canyons with the much thicker post-Humbug sections farther south in the Wasatch Mountains and in the Oquirrh Mountains on the west has not been established. Lithologically, the post-Humbug rocks in the thin section north of the thrust fault are comparable with the basal part of the Great Blue limestone. Pending the availability of paleontologic evidence bearing on the correlation, the writers are inclined to the opinion that the lower part of the Great Blue limestone is represented north and east of the thrust fault and that later Mississippian rocks are not present. It is possible, however, that the limestone and shale of the American Fork-Cottonwood region are equivalent to some part of the Manning Canyon shale which is of upper Mississippian and Pennsylvanian age, contains much interbedded limestone, and normally overlies the Great Blue limestone.
\end{abstract}

The thickness of the Humbug formation, including the Great Blue(?) limestone, is 1,099 feet.

\section{$\underline{\text { Pennsylvanian series }}$}

Formations of Pennsylvanian age are represented in this area by the Morgan formation and the Weber quartzite.

Morgan formation. -In City Creek Canyon, the Morgan formation, cherty limestone about 1,000 feet thick, lies unconformably on the rocks mapped as the Humbug formation and Great Blue(?) limestone. The Morgan formation was not measured in this area because the upper portion is cut out by faulting in one of the principal outcrops, and elsewhere the base of the formation is concealed by overlapping rocks of Tertiary age. That part of the Morgan which is exposed is mostly a gray limestone with flesh-pink chert. Some reddish-brown, green, and black shales were noted in several localities toward the base of the formation. Calkins (1943, p. 28) measured a thickness of 350 feet in the Cottonwood-American Fork area. These beds apparently became sandy to the north where they have been described by Eardley (1944, p. 832), although gray limestone, roughly 275 feet thick and containing pink chert fossils, underlies and interfingers with red sandstone. It has been suggested by Crittenden (personal communication) that because the limestone actually underlies the sandstone at the type locality, it might be termed "lower" Morgan, although in the area mapped it appears more likely that the limestone and sandstone are different facies of the same age.

The Morgan formation grades toward the top into the Weber quartzite.

Weber quartzite. -Overlying the Morgan formation is a thick sequence of yellowish-brown quartzites and a few thin. beds of blue-gray cherty limestones. This formation is involved in faulting that omits or repeats much of the section, which is exposed in the City Creek area. The estimated thickness of the Weber quartzite in this area is about 1, 200 feet, which is the same thickness measured in the Cottonwood-American Fork district by Calkins (1943, p. 29).

The Weber is probably early Pennsylvanian in age, according to Williams (1943, p. 615). This view is also held by Baker, Huddle, and Kinney (1949, p. 1182), who assign the Weber sandstone of the Uinta Mountains to the lower Pennsylvanian series.

\section{PERMIAN SYSTEM}

Park City formation. - The Park City formation overlies the Weber quartzite. While no unconformity was recognized in the area mapped, Blackwelder (1910, p. 532), Baker, Huddle, and Kinney (1949, p. 1188), and J. Stewart Williams (1943, p. 618) have recognized an unconformity north and east of the area.

The Park City formation grades into the underlying Weber quartzite with a series of thin beds of sandy limestone and limy sandstone. For the most part, the formation is made up of limestone with a thick somewhat phosphatic shale in the middle. Some of the limestone is highly fossiliferous and is cherty in part. Measured at the head of Red Butte Canyon, this formation has a total thickness of 974 feet.

\section{TRIASSIC SYSTEM}

Rocks of Triassic age include the Woodside shale, Thaynes formation, and Ankareh shale.

Woodside shale. -The Woodside shale, named and described by Boutwell (1912, p. 52, 77), crops 
out in Dry, Red Butte, and Emigration Canyons and overlies the Park City formation. It is poorly exposed and the true nature of its contacts with the underlying Park City formation and the overlying Thaynes formation could not be observed in detail. The formation consists of pale-brown and thin-bedded shale with thin sandy beds of the same color. The Woodside shale is 384 feet thick at the mouth of Dry Canyon. No fossils from the Woodside in this area have been described, but Hintze (personal communication) reports finding fresh-water pelecypods in the Dry Canyon exposure.

Thaynes formation. - The Thaynes formation was named and described by Boutwell (1912, p. 55). Mathews (1931, p. 15) also described the formation in his report on the rocks of Mesozoic age of the region. On paleontologic evidence, Mathews divided the Thaynes into the Pinecrest and Emigration formations, but these units could not be separated on lithologic evidence during the mapping of the area.

The Thaynes formation consists of a thick series of bluish-white fosslliferous limestone beds interbedded with brown and yellowish-brown shale and pale yellowishbrown sandstone with gradations of all types. At the head of Red Butte Canyon the Thaynes formation is $1,931.5$ feet thick.

Ankareh shale. - The Ankareh shale was measured at the mouth of Parleys Canyon, where it is 1,299 feet thick. It grades into the underlying Thaynes formation and generally consists of reddish-purple shale interbedded with purple sandstone and reddish-brown mudstone. A prominent bed near the middle of the formation has been called the Suicide grit (Williams, J. S., 1945), it is about 60 feet thick and consists of pale purple to white, coarse to gritty quartzite. The type locality of the formation is at Ankareh ridge in the Park City mining district where it was measured and described by Boutwell (1912, p. 58). His measured section of Ankareh shale includes only the basal red beds up to the so-called Suicide grit, which Boutwell called basal Nugget sandstone. The Ankareh as used in this paper, however, includes the so-called Suicide and the shales above it to the base of the Nugget as it is described below. The Ankareh as thus defined probably is equivalent to part of the Moenkopi, the Shinarump, and the Chinle of the Colorado Plateaus (Granger and Sharp, 1952 , p. 12); and further detailed work to the east may, in the future, justify redefinition of the Ankareh.

The Ankareh has few fossils, if any, but is regarded as Triassic on the basis of lithologic correlation with formations of known Triassic age to the north and east.

\section{JURASSIC SYSTEM}

The Nugget sandstone, the Twin Creek limestone, the Preuss sandstone, and the Morrison(?) formation are of Jurassic age.

Nugget sandstone. - The Nugget sandstone overlies the Ankareh shale with a gradational contact. The sandstone is medium grained, orange pink, and crossbedded, with occasional thin beds of platy sandstone. On the mountain front between Emigration and Parleys Canyons, the Nugget sandstone is 830 feet thick. It contains no fossils in this locality. The Nugget is generally thought to be correlative with the Navajo sandstone of southeastern Utah.

Twin Creek limestone. -The Twin Creek limestone overlies the Nugget sandstone with sharp contact. The Twin Creek consists of limestone and shale which are generally pale olive to pale blue and weather yellowish gray. At most outcrops the rocks are folded and crumpled, and the limestone fractures into characteristic pencil-shaped fragments. It is generally fossiliferous and is 2,821 feet thick as measured at the head of Emigration Canyon. The Twin Creek of this area is correlated by Imlay (personal communication) with the formation at the type locality in southwestern Wyoming (Veatch, 1907, p. 56) which contains an abundant Middle Jurassic fauna and is considered by him to be of Middle and early Late Jurassic age.

Preuss sandstone. - The Preuss sandstone is 1, 020 feet thick in Emigration Canyon and consists mainly of pale red interbedded sandstone and shale. This formation overlies the Twin Creek limestone conformably with a slight gradation at the contact. The beds have also been correlated with the Entrada sandstone of southeastern Utah.

Morrison(?) formation. - The Morrison(?) formation, which in the field has been called the "White Marker, "is at the top of the Jurassic section and separates the underlying Preuss formation from the overlying Kelvin formation. The Morrison(?) formation, though thin (102 feet thick as measured in Parleys Canyon), is very persistent. Light-gray algal limestone, which weathers chalky white, makes up most of the formation. A few thin beds of sandstone and a thin white conglomerate that contains polished pebbles are sometimes interbedded with the limestone, but either or both of these thin members may be missing in certain localities. It forms a prominent band of white chalky outcrops in Emigration and Parleys Canyon.

\section{CRETACEOUS SYSTEM}

Formations of Cretaceous age include the Kelvin formation, the Frontier formation, and an unconformable conglomerate of questionable age.

Kelvin formation. - The Kelvin formation which overlies the Morrison formation with apparent con-. formity is made up of red siltstone, purple-red sandstone, and sandy conglomerate which contains mostly well-rounded pebbles of Weber quartzite and a few pebbles of Carboniferous limestone. The formation is 1,567 feet thick as measured in upper Parleys Canyon. It was named by Mathews (1931, p. 48).

Frontier formation. --The Frontier formation as measured in East Canyon is 8, 724 feet thick and grades into the Kelvin formation at its base. The Frontier formation consists of pale yellowishbrown somewhat fossiliferous sandstone interbedded with pale yellowish-brown to pale-red tuffaceous clay and a few beds of conglomerate made up chiefly of sandstone boulders in a sandy matrix. Tuffaceous beds similar to the "porcelainites" of the Aspen shale of southwestern Wyoming crop out near the base. Conglomerate beds increase in thickness and number near the top. 
Conglomerate. - A conglomerate of Cretaceous age overlies the Frontier formation with a marked angular unconformity. It contains mostly pebbles and boulders of sandstone of the Frontier formation with some of Weber quartzite and a few boulders of Carboniferous limestone. The age of the conglomerate is probably roughly equivalent to the Price River or North Horn formations of central Utah (Spieker, 1946, p. 130). Fossil evidence is missing, but relationships with the older formations and the folding and faulting of the conglomerate suggests the correlation. The conglomerate was not mapped far enough to the north to provide a basis for correlation with those described by Eardley.

\section{TERTIARY SYSTEM}

Four formations of probable Tertiary age have been distinguished in the area north and east of Salt Lake City. The lowest of these is a conglomerate provisionally correlated with the Almy formation. The conglomerate grades upward into a series of interbedded tuffaceous sediments and limestones provisionally correlated with the Fowkes formation, which are in turn overlain unconformably by a series of andesitic volcanic rocks. All three of these units are overlapped by a flat-lying conglomerate provisionally correlated with the Knight formation of Eardley (1944).

Conglomerate No. 1. -Overlying the conglomerate of Cretaceous age and overlapping the older rocks north of Parleys summit is a conglomerate provisionally correlated with the Almy formation (Eardley, 1944 , p. 842; also p. 54). This conglomerate is distinguished from the underlying Cretaceous conglomerate on the basis of an unconformity between the two, and because of an abrupt and marked change in composition. Boulders of pre-Cambrian and Tintic quartzite are abundant in this unit but are entirely absent from the Cretaceous conglomerate. Boulders of limestone are also conspicuously more abundant in Conglomerate No. 1.

A conglomerate of similar lithologic character and that occupies a similar stratigraphic position is exposed near the mouth of City Creek. It, too, is provisionally correlated with the Almy formation; it may also be equivalent in part to Spieker's (1946, p. 132) North Horn formation.

Limestone. - On the Salt Lake salient, Conglomerate No. 1 is overlain conformably by about 800 feet of poorly consolidated red sandstone, sandy limestone, and water-laid tuff with some interbedded pale gray limestone. These beds are best exposed along a creek that flows northwest across the terraced lake shore below the Bonneville level on the northwest corner of the Salt Lake salient. They are also well exposed in road cuts along the Victory Highway north of the State Capitol, and crop out in City Creek Canyon and at a few places farther east. These sediments are provisionally correlated with the Fowkes formation (Eardley, 1944, p. 844) because of their lithologic similarity to it and their position between older and younger Tertiary(?) conglomerates.

Andesite. - The next younger unit in the sequence exposed in the Salt Lake salient is a group of redweathering andesitic flows and breccias which in places rests on the above-mentioned limestone, and at places overlaps the Conglomerate No. 1. Similar andesite occurs in small patches near the crest of the divide at the head of Parleys Canyon, but here it rests on steeply dipping rocks of Jurassic or Cretaceous age and does not appear between Conglomerates No. 1 and No. 2.

Conglomerate No. 2. -Overlying unconformably all other units described as Tertiary(?), and overlapping the basement rocks of all ages, is a nearly flat-lying conglomerate provisionally correlated with the Knight formation (Eardley, 1944, p. 844). In composition this unit is more diverse than any other, and it appears to have been reworked from the underlying beds. It was certainly deposited upon a surface of strong relief, and accumulated to depths of several thousand feet against the front of the range beneath the Salt Lake salient.

It is not involved in any of the major folding that has affected the older conglomerates or the rocks of Mesozoic age. In Parleys Canyon it overlaps a fault that cuts all of the older rocks.

\section{STRATIGRAPHIC SECTIONS}

Section of Brigham quartzite on North Fork Creek north and east of Rotary Park, City Creek Canyon

Ophir shale.

Brigham quartzite:

Quartzite, medium-to fine-grained, pale-orange, pink to white; quite resistant, crops out well-_..--- 260

Quartzite, medium-grained to gritty locally, white; does not crop outwell-....

Quartzite, fine-grained, pale-pink, small white quartzite pebbles locally; crops out well-..........

Quartzite, medium-grained, very pale orange to

white rust stains, softer than usual-

Quartzite, medium-grained, pale orange-pink to

pale olive, a few white quartzite pebbles-

Quartzite, coarse-grained, grayish-olive-green-1......

Quartzite, medium-grained, pale orange-pink to

pale olive, few white quartzite pebbles

Quartzite, coarse-grained, pale orange;

few white quartzite pebbles, rusty stained 
Maxfield limestone.

Ophir shale:

Shale, soft, pale-olive, somewhat micaceous-1

Limestone, massive, medium bluish-gray-_

Shale, micaceous, light olive-gray and dark yellowish-brown; weathers rusty--

Limestone, medium, bluish-gray, mottled yellowish-brown-1

Shale, micaceous, light olive-gray and dark yellowish-brown; weathers rusty

Shale, alternating layers of grayish-purplif and dark yellowish-brown about 1 foot to 2 feet thick,

fairly resistant-..-

Quartzite, pale-pink, medium-grained, hard _- 4

Shale, micaceous, pale yellowish-brown; weathers dark

Quartzite, pale-pink, medium-grained, hard--_.

Shale, micaceous, pale yellowish-brown; weathers dark

Brigham quartzite.

Section of Maxfield limestone on North Fork Creek north and east of Rotary Park, City Creek Canyon

Swan Peak(?) formation.

Maxfield limestone:

Limestone, dolomitic in part, massive, medium gray, streaked with light-gray, resistant $\ldots \ldots$

Limestone, light olive-gray; weathers yellowish-gray to white; laminated in part-...................

Limestone, dolomitic in part, massive, medium-gray, streaked with light-gray, resistant-...... 40

Limestone, light-olive-gray; weathers medium-gray to white-1

Limestone, dolomitic in part, massive, medium-gray, streaked with light-gray, resistant--...-.-- 271

Limestone, medium-bedded, medium bluish-gray, somewhat mottled pale yellowish-brown--...- 55

Limestone, thin-bedded to shaly, medium bluish-gray; weathers light bluish-gray; mottled pale yellowish-brown-1.

Limestone, medium-bedded, medium bluish-gray, somewhat mottled pale yellowish-brown

Limestone, thin-bedded to shaly, medium bluish-gray; weathers light bluish-gray; mottled pale yellowish-brown-_.

Ophir shale.

Section of Swan Peak(?) formation on North Fork Creek north and east of Rotary Park, City Creek Canyon

Pinyon Peak limestone.

Swan Peak(?) formation:

Quartzite, coarse-grained, pale yellowish-brown-10

Quartzite, hard rib, fine-grained, pale yellowish-brown to white-1-

Quartzite, sandy in part, pale yellowish-brown to pale reddish-brown, coarse-grained-........... 36

Quartzite, pale yellowish-brown, medium-grained-_...

Quartzite, hard rib, pale red-purple, medium-grained-_.

Quartzite, sandy in part, pale yellowish-brown to pale reddish-brown, coarse-grained -

Maxfield limestone.

Section of Pinyon Peak limestone on North Fork Creek north and east of Rotary Park, City Creek Canyon

Madison limestone.

Pinyon Peak limestone:

Limestone, thin-to medium-bedded, bluish-gray, mottled pale yellowish-brown to pale red---..--

Limestone, thin-bedded to shaly, pale olive-_.

Iimestone, hard rib, thick-bedded, bluish-gray; weathers light bluish-gray; flaggy fracture, somewhat fossiliferous-1.

Limestone, thin-bedded, bluish-gray to olive-gray, mottled yellowish-gray; flaggy fracture, somewhat fossiliferous-

Swan Peak(?) formation. 
Deseret limestone.

Madison limestone:

Dolomite, medium-bedded, medium-gray, grayish-black chert nodules, fine-grained, phosphatic in part-

\section{weathers medium bluish-gray; some medium-gray chert, somewhat fossiliferous}

Limestone, fine-grained, dark bluish-gray; weathers medium bluish-gray;

fossiliferous, some yellowish-gray mottling, thin- to medium-bedded-1

Limestone, somewhat dolomitic, thick-bedded to massive, medium- to coarse-grained,

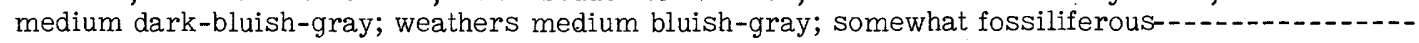

Pinyon Peak limestone.

\section{Section of Deseret limestone on south side of canyon above Rotary Park in City Creek Canyon}

Humbug formation.

Deseret limestone:

Dolomite, limy and sandy locally, medium dark-gray; weathers medium-gray; chert nodules, medium- to coarse-grained, medium- to thick-bedded--

Limestone, medium- to fine-grained, dolomitic, medium-gray; weathers light-gray;

few light-gray chert nodules; thick-bedded to massive-1

Dolomite, fine-grained, medium-dark gray, abundant dark- to medium-gray chert, somewhat sandy, medium-bedded-1

Shale, grayish black; weathers medium-gray, thin- to thick-bedded-c-

Madison limestoné.

\section{Section of Humbug formation on south side of canyon above Rotary Park in City Creek Canyon}

Morgan formation.

Great Blue(?) limestone and Humbug formation:

Limestone, fine-grained, dark-gray; weathers light-gray; somewhat fossiliferous, medium- to thick-bedded, locally thin-bedded; a 1-foot sandstone bed, pale yellowish-brown, lies 22 feet above base-.

Sandstone, quartzitic, medium-grained, moderate yellowish-brown-1

Limestone, sandy, medium-gray; weathers yellowish-gray-_.

Limestone, dark-gray; weathers light-gray; thick-bedded-1

Limestone, sandy, medium light-gray to yellowish-_

Limestone, dark-gray; weathers medium light-gray-1

Sandstone, pale yellowish-brown-10

Limestone, sandy locally, medium-gray to yellowish-gray-a

Sandstone, crossbedded, yellowish-gray to pale yellowish-brown, streaked pale-red locally-......-

Dolomite, coarse-grained, medium dark-gray; weathers medium light-gray-_..................-

Sandstone, crossbedded, yellowish-gray to pale yellowish-brown, streaked pale-red locally-......

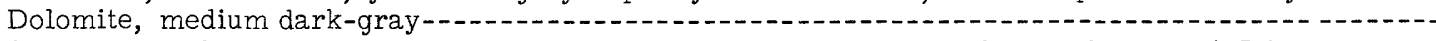

Sandstone, pale yellowish-brown with alternating beds of medium dark-gray dolomite 4-5 feet thick---

Limestorie, medium-gray, somewhat fossiliferous-_-

Sandstone, crossbedded, pale yellowish-brown

Sandstone, pale yellowish-brown; interbedded with medium dark-gray dolomite 5 feet thick

Sandstone, crossbedded, pale yellowish-brown-1

Limestone, medium light-gray;

somewhat fossiliferous

Sandstone, crossbedded, pale yellowish-brown-1

Dolomite, dark-gray; weathers medium

light-gray; medium-grained, thick-bedded-1

Sandstone, crossbedded, pale yellowish-brown-...

Dolomite, dark-gray; weathers medium light-gray; medium-grained, thick-bedded-1-

Sandstone, crossbedded, pale yellowish-brown-

Deseret limestone. 
Weber quartzite.

Morgan formation (upper part of formation absent through faulting):

Limestone, gray, locally mottled with tan sandy material, flaggy fracture, somewhat fossiliferous---- 61

Shale, green to tan; weathers rusty-1

Limestone, pale reddish-gray, highly fossiliferous, with crinoid stems

Limestone, gray, sandy-

Shale, dark red to green-1.

Limestone, pale blue to gray; pink chert nodules and pink chert fossils

Shale, black-1-.--

Limestone, pale blue, mottled tan; flaggy fracture

Sandstone, tan, fine-grained-1an; flaggy fracture-1

Shale, black; weathers rusty; flaggy fracture

Unconformity

Great Blue(?) limestone and Humbug formation.

\section{Section of Park City formation on divide between Red Butte and Emigration Canyons}

Woodside shale.

Park City formation:

Limestone, medium bluish-gray to gray; weathers light bluish-gray to

yellowish-gray; sandy in part, fossiliferous

Shale, thick-bedded, somewhat phosphatic, dark-gray -

Sandstone, light olive-gray; with phosphatic chert lenses, medium bluish-gray to dark-gray--.---- 37

Shale, thick-bedded, phosphatic, cherty, medium bluish-gray-_.

Limestone, light-gray, chert at top, phosphatic

Limestone, sandy, yellowish-gray to gray, with gray chert nodules-

Sandstone, light olive-gray; weathers yellowish-gray-a

Shale, dark - to medium-gray; thin- to medium-bedded, somewhat phosphatic, bluish-gray chert nodules-10

Sandstone, shaley, gray to yellowish-gray, with medium bluish-gray to dark-gray chert nodules-.

Limestone, fine-grained, dark-gray to grayish-black; weathers light-gray; phosphatic, fossiliferous, cherty, thin-bedded-140

Limestone, massive, light olive-gray; weathers medium-gray;

fossiliferous, very resistant-_.

Limestone, sandy, light-gray, gray chert nodules

Sandstone, limy, pale-pink to pale yellowish-brown; some breccia-

Limestone, sandy, light-gray-a

Sandstone, pale yellowish-brown-1.

Limestone, light-gray; brecciated in part-_- 33

Sandstone, pale yellowish-brown; some breccia-_.

Limestone, light-gray--

Weber quartzite.

Thaynes formation.

Woodside shale:

Shale, pale yellowish-brown-

Limestone, sandy, gray--

Shale, pale-brown, becoming sandy locally; ripple marks abundant-1...

Shale, pale yellowish-brown to brown; ripple marks abundant

Sandstone, pale-brown locally streaked with brown; generally crops out-1.

Shale, pale-brown--

Shale, pale-brown with interbedded yellowish-gray limestone-1-

Limestone, sandy, yellowish-gray-a

Shale, limy, yellowish-gray-a

Shale, pale yellowish-brown-1 
Woodside shale-Continued

Shale, pale-brown, sandy locally

Limestone, yellowish-gray, lenticular-

Shale, pale-brown, sandy iocally-n

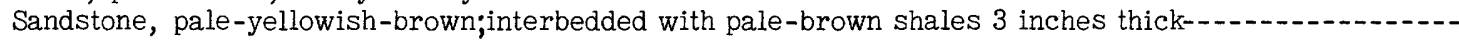

Park City formation.

\section{Section of Thaynes formation on ridge between Red Butte and Emigration Canyons}

Ankareh shale.

Thaynes formation:

Sandstone, limy, yellowish-tan; interbedded with bluish-white limestones and some thin

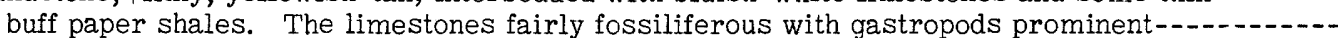

Shale, sandy, greenish-buff

Sandstone, limy, yellowish

Limestone, bluish-white; pelecypods abundant

Limestone, bluish-white; pelecypod fragments; sandy in part

Shale, fissile, yellowish-brown-1

Limestone, sandy lenses, yellowish-tan

Sandstone, yellowish-buff; grading into limy lenses-_.

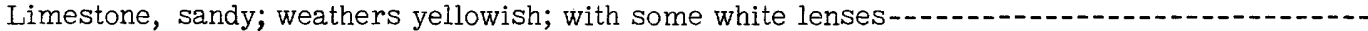

Shale, greenish-brown-1

Limestone, sandy, yellowish; with white limestone lenses

Shale, greenish-buff--

Limestone, sandy, yellowish-buff; local white lenses -

Shale, brown, fissile; 2-foot limestone bed

Limestone, sandy, yellowish-buff; becoming locally fine-grained and pure

Shale, brown, fissile-1.-

Limestone, sandy, buff--

Shale, brown, fissile-1

Limestone, sandy, buff

Shale, brown, fissile -

Limestone, bluish-white; pelecypod fragments -

Shale, brown, fissile-1

Limestone, bluish-white-1

Shale, brown, fissile-_.

Limestone, bluish-white; pelecypod fragments-

Shale, greenish-brown, fissile-1

Sandstone, limy, yellowish-buff

Shale, brown, fissile-1

Sandstone, limy, yellowish-tan; shaly in part-

Shale, brown, fissile-1.-

Limestone, sandy, greenish-buff; shaly in part-

Shale, greenish; with limestone blebs-

Limestone, yellowish-tan; fresh fracture, blue-1

Shale, greenish-brown--

Limestone, sandy, yellowish- to brown-weathering-

Shale, greenish, with brown mudstone blebs

Limestone, bluish-white -

Shale, buff to brown, sandy in part

Limestone, bluish-white; pelecypod fragments-

Shale, greenish-brown; some interbedded sandy limestones-

Shale, reddish-brown--

Shale, greenish-brown, few thin sandy beds-

Limestone, yellowish-tan, sandy-cos

Shale, reddish-brown-...

Limestone, bluish-white; pelecypod fragments-

Shale, yellowish-brown; with few beds of limestone 1 foot and 2 feet thick

Limestone, white, weathered; blue, fresh fracture; pelecypods

Shale, green to reddish-brown-1

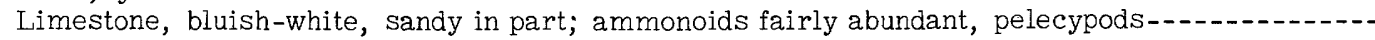

Shale, brown to tan- 
Thaynes formation -Continued

Sandstone, limy and shaly, tan to yellow

Limestone, bluish-white, sandy in part; ammonoids present on weathered surfaces-.

Limestone, sandy to shaly, yellow to tan for most part; some bluish-white limestone lenses -

Woodside shale.

Section of Ankareh shale on south side of Parleys Canyon at mouth

Nugget sandstone.

Ankareh shale:

Shale, purple, thin-bedded, sandy in part

Sandstone, massive, crossbedded, orange-pink (nuggetlike)

Sandstone, purple, medium-bedded, somewhat quartzitic-

Sandstone (nuggetlike) -

Mudstone, red-1

Sandstone (nuggetlike)

Sandstone, purple, medium-bedded, somewhat quartzitic, with a few

interbedded soft red sandy shales- somewhat quartzitic, with a few

Mudstone, chocolate-red, massive; has leaching in

spherical-shaped bodies up to 3 inches in diameter

Shales, purple; weathers soft-1

Limestone, dense; weathers white; fresh fracture, pale purple; few fossils present...

Sandstone, purple, medium-crossbedded, somewhat quartzitic-

Quartzite, Suicide member, crossbedded; hard, somewhat lensing in character; pale-purple to white--- 60

Mudstone, chocolate-red, massive, with spherical leaching

Sandstone, purple, medium-bedded-10

Shale, soft, reddish-purple and greenish, sandy in part

Sandstone, purple, with interbedded red shales, ripple marks abundant-_.

Sandstone, purple, medium-crossbedded, somewhat quartzitic

Shale, soft, red and green, interbedded purple sandstones

Sandstone, brownish buff-1.

Shale, soft, red, with some interbedded brown sandstones

Thaynes formation.

Section of Nugget sandstone on north side of Parleys Canyon at mouth

Twin Creek limestone.

Nugget sandstone:

Sandstone, orange-pink, with a few thin beds of limestone-1

Sandstone, orange-pink; massive, becoming locally thin-bedded, flagstone type; crossbedded in part-- 250

Sandstone, orange to pink becoming limy in lenses-

Sandstone, orange pink; massive becoming

locally thin-bedded, flagstone type; crossbedded generally

Ankareh shale.

\section{Section of Twin Creek limestone on north side of Emigration Canyon}

Preuss sandstone.

Twin Creek limestone:

Limestone, thin-to medium-bedded; weathers grayish-orange to gray;

fresh fracture light olive-gray, sandy in part-
Limestone, thin-bedded; weathers very pale orange to gray; fresh fracture pale-blue

to gray; becomes fissile locally

Shale, limy, fractures in pencillike forms; weathers yellowish-gray; fresh fracture pale-olive-...-.-.- 
Twin Creek limestone -Continued

Limestone, shaly; fractures in pencillike forms; weathers pale-gray; fresh fracture pale-blue-......--

Shale, pencilform, pale-olive-1

Limèstone, pencilform, pale-blue-1.

Shale, pencilform-1

Limestone, pencilform-1..-

Limestone, sandy; weathers yellowish-brown; fresh fracture moderate-yellowish-brown -...........

Shale, pencilform, becoming locally sandy, pale brown-1

Limestone, pencilform-1

Sandstone, limy, pale-brown-1

Shale, pencilform, becoming locally sandy, pale-brown-1

Limestone, pencilform to thick-bedded; weathers yellowish-gray; fresh fracture pale-blue -...-..-.

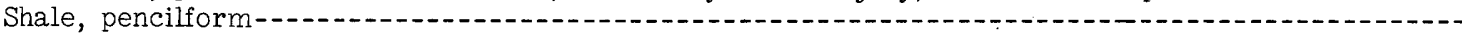

Limestone, medium-bedded generally; weathers yellowish-gray; fresh fractures pale-blue -...-...---

Limestone, sandy, massive, grayish-yellow

Limestone, medium-bedded; weathers yellowish-gray-1

Limestone, massive; weathers gray; fresh fracture grayish-blue

Shale, pencilform, with beds of limestone; pale-blue, sandy locally

Limestone, massive, grayish-blue-1

Shale, pencilform-1.-

Limestone, pencilform to medium-bedded, pale-blue; weathers yellowish-gray--

Limestone, medium-bedded, pale-blue; with several horizons of fossiliferous material up to

1 foot thick and about 40 feet from the base, lenticular

Nugget sandstone.

55

33

27

27

71

32

115

95

6

120

170

Section of Preuss sandstone on south side of summit, Parleys Canyon

Morrison(?) formation.

Preuss sandstone:

Sandstone, medium- to coarse-grained, pale red; with a few interbedded pale red shales. Sandstones weather in rounded cobblelike forms

Shale, pale-red with some interbedded pale-red siltstones and

Sandstone, pale red to yellowish-brown, medium-to coarse-grained; with some interbedded pale red shales-.........

Limestone, sandy, yellowish-gray to yellowish-brown, medium- to coarse-grained-_.................

Sandstone, pale red; with some interbedded pale red shales

Twin Creek limestone.

\section{Section of Morrison(?) formation on north side of summit, Parleys Canyon}

Kelvin formation.

Morrison(?) formation:

Siltstone, soft, pale-red; with interbedded very light gray limestone-1...

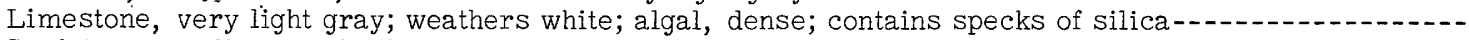

Sandstone, medium-grained, pale red-_.

Conglomerate, white sandy matrix, pebbles well-rounded, polished,

mostly Weber, some white sandstone, some older dark quartzites-a

Preuss sandstone.

Section of Kelvin formation on north side of Parleys Canyon, east of Mountain Dell reservoir

Frontier formation.

Kelvin formation:

Conglomerate, well-rounded boulders up to 1 foot in diameter, mostly Weber, some Nugget, some Entrada; coarse red matrix - 
Section of Kelvin formation on north side of Parleys Canyon, east of Mountain Dell reservoir-Continued

Kelvin formation - Continued

Siltstone, soft, moderate reddish-brown

Sandstone, soft, limy, occasional pebbles, pale red-

Sandstone, soft, cross-bedded, white; weathers pale red

Siltstone, ribs of coarser grained sandstone, moderate reddish-brown-1-

Sandstone, medium-grained, bedding 1-18 inches, crossioedded,

pale reddish-brown, occasional beds of conglomerate $\frac{1}{4}$-inch pebbles-

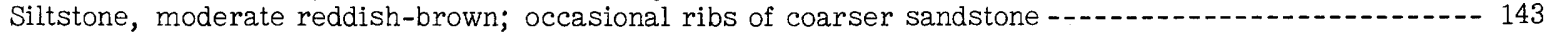

Sandstone, rib, pale reddish-brown, fine-grained, hard-ben

Siltstone, moderate reddish-brown; occasional ribs of coarser sandstone

Sandstone, rib, pale reddish-brown, fine-grained, hard-10

Siltstone, moderate reddish-brown; occasional ribs of coarser sandstone -

Conglomerate, well-rounded pebbles up to 3 inches in diameter, mostly Weber,

some older quartzites; coarse white sandy matrix

Sandstone, grayish-pink; weathers pale reddish-brown-1

Conglomerate, white sandy matrix, same as above-1

Sandstone, pale red, cross-bedded, pale reddish-brown

Conglomerate, red matrix, $\frac{1}{2}$-inch quartzite pebbles, well-rounded-1. 6

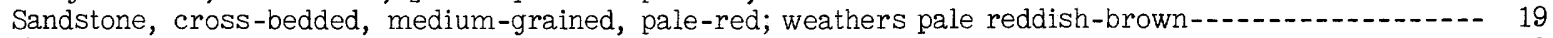

Siltstone, moderate reddish-brown; with occasional coarser sandstones, 1-2 feet thick

Conglomerate, pale-red sandy matrix, pebbles up to 3 inches in diameter,

polished, mostly Weber, some older quartzites-a

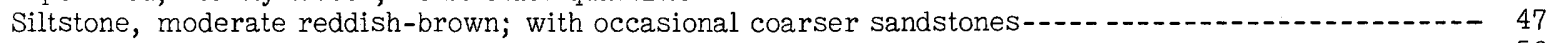

Sandstone, pale red-purple, medium-grained-_.

Sandstone, pale red; weathers white; occasional siltstone

Siltstone, moderate reddish-brown, sandy locally-1.-

Sandstone, pale-red, weathers pale reddish-brown; medium-grained-_.

Siltstone, moderate reddish-brown, sandy locally

Sandstone, pale-red, medium-grained-1

Sandstone, hard, pale-purple; weathers pale reddish-brown to white-1...

Siltstone, soft, moderate reddish-brown-1

Sandstone, yellowish-brown, medium-grained--

Conglomerate, quartzite pebbles up to 3 inches in diameter, pale red matrix

Siltstone, moderate reddish-brown, soft; occasional red-purple sandstone beds 1 foot thick

Morrison(?) formation.

Section of Frontier formation on east side of upper East Canyon

Conglomerate.

Unconformity.

Frontier formation:

Sandstone, thin-bedded to massive, fossiliferous locally,

pale yellowish-brown to white, coarse-grained, locally soft-1

Clay, locally sandy and tuffaceous, soft, pale yellowish-brown to pale red-163

Sandstone, thin to medium-bedded, coarse-grained, pale yellowish-brown

Clay, locally sandy and tuffaceous, soft, pale yellowish-brown to pale red

Sandstone, coarse-grained, pale yellowish-brown-186

Sandstone, coarse-grained, pale yellowish-brown, thin-to medium-bedded,

very soft locally, giving ribbed outcrop--

Clay, locally sandy and tuffaceous, soft, pale yellowish-brown to pale red.-189

Sandstone, coarse-grained, pale yellowish-brown

Clay, locally sandy and tuffaceous, soft, pale yellowish-brown to pale red

Sandstone, medium-bedded, coarse-grained, pale yellowish-brown-163

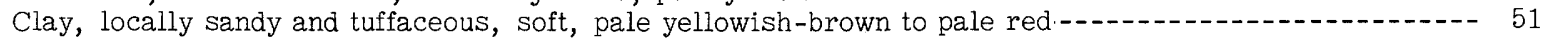

Sandstone, medium-bedded, coarse-grained, pale yellowish-brown-1 79

Clay, locally sandy and tuffaceous, soft, pale yellowish-brown to pale red.

Sandstone, coarse-grained, pale-yellowish-brown to pale red-16

Clay, locally sandy and tuffaceous, soft, pale-yellowish-brown to pale red-1.

Sandstone, pale yellowish-brown to white

Clay, locally sandy and tuffaceous, soft, pale yellowish-brown to pale red

Sandstone, pale yellowish-brown to white-cou

Clay, locally sandy and tuffaceous, soft, pale yellowish-brown to pale-red-1.

Sandstone, pale yellowish-brown to white-18 
Frontier formation - Continued

Clay, locally sandy and tuffaceous, soft, pale yellowish-brown to pale-red-1

Sandstone, pale yellowish-brown, hard-1

Clay, locally sandy and tuffaceous, soft, pale yellowish-brown to pale red

Sandstone, pale yellowish-brown to white, hard

Clay, locally sandy and tuffaceous, soft, pale yellowish-brown to pale-red-... 93

Sandstone, pale yellowish-brown to white, hard

Clay, locally sandy and tuffaceous, soft, yellowish-gray to white

Sandstone, pale yellowish-brown to white, hard -

Clay, locally sandy and tuffaceous, soft, yellowish-gray to white-1

Sandstone, pale yellowish-brown to white, hard--

Clay, locally sandy and tuffaceous, soft, yellowish-gray to white-100

Sandstone, pale yellowish-brown to white, hard-

Sandstone, soft, yellowish-gray, coarse-grained--

Sandstone, hard, pale yellowish-brown to white-

Sandstone, soft, yellowish-gray, coarse-grained-1

Sandstone, hard, pale yellowish-brown to white-

Sandstone, soft, yellowish-gray, coarse-grained-195

Sandstone, hard, pale yellowish-brown to white-

Sandstone, soft, yellowish-gray, coarse-grained-1

Sandstone, hard, pale yellowish-brown to white-

Sandstone, soft, yellowish-gray, coarse-grained-1.

Sandstone, hard, pale yellowish-brown to white-

Sandstone, soft, yellowish-gray, coarse-grained-

Sandstone, very soft, tuffaceous, gray-

Sandstone, alternating hard white and soft coarse yellowish-brown

Shale, sandy, yellowish-gray

Sandstone, white, limy, coarse, some thin beds of conglomerate

Shale, sandy, yellowish-gray-

Conglomerate, pebbles up to 2 inches in diameter

Sandstone, yellowish-gray, coarse-grained; occasional bed of conglomerate with

pea-sized subangular pebbles-1

Conglomerate, sandy matrix, well-rounded pebbles with boulders up to

1 foot in diameter, mostly Weber

Grit, sandy, light-gray; weathers pale yellowish-brown-140

Shale, sandy, yellowish-gray-

Sandstone, white, limy, coarse-grained -

Sandstone, tuffaceous, light-gray; weathers pale yellowish-brown

Shale, sandy, yellowish-gray-1

Sandstone, white, limy, coarse-grained-1

Shale, sandy, yellowish-gray-10

Sandstone, light greenish-gray, coarse-grained-1

Conglomerate, well-rounded pebbles up to 6 inches in diameter, Weber and chert-1

Sandstone, light greenish gray; weathers pale yellowish-brown-130

Sandstone, soft, very coarse, pale reddish-brown

Sandstone, hard, white, limy, coarse-grained-1 9

Sandstone, soft, very coarse, pale reddish-brown-102

Kelvin formation.

\section{SELECTED BIBLIOGRAPHY}

Baker, A. A., Huddle, J. W., Kinney, D. M. , 1949, Paleozoic geology of the north and west sides of Uinta Basin, Utah: Am. Assoc. Petroleum Geologists Bull. , v. 33, p. 1161-1197.

Bell, G. L., 1952, Geology of the central Wasatch Mountains, Utah: Utah Geol. Soc. Guidebook 8th Ann. Field Conf., 1952.

Blackwelder, Elliott, 1910, New light on the geology of the Wasatch Mountains, Utah: Geol. Soc. America Bull. , v. 21, p. 517-542, 747.

Boutwell, J. M. , 1912, Geology and ore deposits of the Park City district, Utah: U. S. Geol. Survey Prof. Paper 77.
Calkins, F. C., and Butler, B. S., 1943, Geology and ore deposits of the Cottonwood-American Fork area, Utah: U. S. Geol. Survey Prof. Paper 201.

Eardley, A. J. , 1944, Geology of the north-central Wasatch Mountains, Utah: Geol. Soc. America Bull. , v. 55, p. 819-894.

Gilluly, James, 1932, Geology and ore deposits of the Stockton and Fairfield quadrangles, Utah: U. S. Geol. Survey Prof. Paper 173.

Goddard, E. N. , and others, 1948, Rock-color chart: 6 p. , 6 charts, Washington, Natl. Research Council. Granger, A. E., and Sharp, B. J., 1952, Geology of the central Wasatch Mountains, Utah, in Utah Geol. Soc. Guidebook 8th Ann. Field Conf. , 1952 
Mathews, Asa A. L., 1931, Mesozoic stratigraphy of the central Wasatch Mountains: Oberlin Coll. Lab. Bull., n. ser., v. 1, 50 p.

Mansfield, G. R., 1927, Geography, geology, and mineral resources of part of southeastern Idaho: U. S. Geol. Survey Prof. Paper 152.

Richardson, G. B., 1941, Geology and mineral resources of the Randolph quadrangle, Utah-Wyo. : U. S. Geol. Survey Bull. 923.

Spieker, E. M. , 1946, Late Mesozoic and early Cenozoic history of central Utah: U. S. Geol. Survey Prof. Paper 205-D.
Veatch, A. C., 1907, Geography and geology of a portion of southwestern Wyoming, with special reference to coal and oil: U. S. Geol. Survey Prof. Paper 56.

Williams, J. Stewart, 1943, Carboniferous formations of the Uinta and northern Wasatch Mountains, Utah: Geol. Soc. America Bull., v. 54, p. 591-624. 1945, Nomenclature of Triassic rocks in northeastern Utah: Am. Jour. Sci., v. 243, p. $473-479$. 